\title{
Effect of Fibrin Sealant on Knee Function Restoration Following Total Knee Replacement: A Meta-analysis
}

Kongye Lu ( $\square$ lukongye@icloud.com )

Northern Jiangsu People's Hospital https://orcid.org/0000-0001-8055-4270

Mengqi Lu

tongde hospital of zhejiang province

Yunlong Pei

northern jiangsu people's hospital

Pengzhi Shi

northern jiangsu people's hospital

Jin Zhang

I.M. Sechenov First Moscow State Medical University of the Ministry of Health of the Russian Federation (Sechenov University))

Tuanjie Hou

Northern jiangsu people's hospital

Xiao Chen

Northern Jiangsu People's Hospital

Research article

Keywords: Fibrin sealant, total knee replacement, knee function restoration, hemostasis, meta-analysis

Posted Date: November 15th, 2021

DOI: https://doi.org/10.21203/rs.3.rs-1061229/v1

License: (c) (i) This work is licensed under a Creative Commons Attribution 4.0 International License. Read Full License 


\section{Abstract}

Objective: The aim of present study was to evaluate the efficacy and safety of fibrin sealant on knee function restoration following total knee replacement.

Methods: PubMed, Web of Science, Cohrane library, and Embase were searched up to August 2021. All prospective randomized controlled trial involving fibrin sealant treatment for total knee replacement were included in this meta-analysis. Range of motion, total blood loss, blood transfusion rate, hemoglobulin reduction, hospital stay, and complication were calculated using RevMan 5.4 software.

Results: Totally 23 randomized clinical trials involving 2267 patients ( 1136 patients for fibrin sealant group and 1131 patients for control group) were finally included. The results indicated that that the usage of fibrin sealant in total knee replacement can reduce the total blood loss [95\% (-935.81, -351.70$)$, $\mathrm{P}<0.0001]$, transfusion rate $[95 \% \mathrm{Cl}(0.47,0.90), \mathrm{P}=0.01]$, hemoglobulin reduction [95\% $\mathrm{Cl}(-2.94,-0.74), \mathrm{P}=0.001]$ and hospital stay [95\% $\mathrm{Cl}(-1.76,-0.42)$, $\mathrm{P}=0.001]$ without increasing the rate of complication $[95 \% \mathrm{Cl}(-0.04,0.02), \mathrm{P}=0.42]$, but cannot increase the knee range of motion [95\% $\mathrm{Cl}(-1.17,9.29), \mathrm{P}=0.13]$

Conclusion: The usage of fibrin sealant can effectively reduce the total blood loss, transfusion rate, hemoglobulin reduction and hospital stay without increasing the rate of complication, but cannot increase the knee range of motion

\section{Introduction}

As the population aged, total knee replacement (TKR) procedures performed for the treatment of knee arthritis has increased recently. By 2030 , the demand for primary total knee arthroplasties is projected to grow to 3.48 million procedures in Unites States.[1] Furthermore, TKR is increasingly performed in two-day or even one-day surgery, requiring immediate postoperative full ambulation.[2] Thus, in addition to a satisfactory intra-operation blood loss control, a rapid knee function recovery become much more important for patients undergoing total knee replacement. Previous studies have focused on blood loss and reported significant postoperative blood loss range from $1200 \mathrm{ml}$ to $1800 \mathrm{ml}$ or even higher due to hidden blood loss.[3] Although a tourniquet is always used during operation, studies showed torniquet application could not reduce the blood loss but increase the incidence of postoperative deep venous thrombosis and aggravate postoperative pain and swelling.[4, 5] What's more, as a key indicator for knee function, knee range of motion might be limited due to post-operation scar or tissue adhesion after total knee replacement, leading to persistent knee pain, patient dissatisfaction and even revision. A full range of motion (ROM) recovery is usually an indicator for patient discharge.

Fibrin sealant (FS), comprised mostly of fibrinogen and human thrombin, can initiate the last phase of physiological blood coagulation and reduce postoperative blood loss theoretically.[6] Over the past decades, although fibrin sealant has been widely used in surgical procedures, the effects of fibrin sealant on knee surgery remain controversial. On the one hand, some studies reported successfully reduced blood loss, along with lower blood transfusion rate and blood transfusion unit by using fibrin sealant in total knee replacement while other studies against it.[7-11] On the other hand, blood transfusion rate used to be a great concern before modern transfusion trigger protocols were introduced. Hoverer, blood transfusion rate has decreased tremendously nowadays and is no longer a major concern after total knee replacement.[12] Moreover, with the concept of Enhanced Recovery After Surgery, outcomes related to knee function and recovery speed are increasingly considered important, demonstrating a focus shift of the fibrin sealant.

Recently, several randomized controlled trials (RCTs) reported the effect of fibrin sealant on knee functions after total knee replacement published, while there is no consensus achieved. Thus, we perform this meta-analysis to further identify the efficacy of fibrin sealant on TKR. The purpose of this meta-analysis was to determine the effect of fibrin sealant on knee function restoration after total knee replacement in terms of total blood loss, hemoglobulin reduction, blood transfusion rate, hospital stay, complications and most importantly knee range of motion.

\section{Materials And Methods}

This study was performed according to the Preferred Reporting Items for Systemic Reviews and Meta-Analysis (PRISMA) guidelines.

\section{Search strategy}

PubMed, Web of Science, Cohrane library, and Embase were searched up to August 2021 by two reviewers for prospective randomized controlled trial involving fibrin sealant treatment for total knee replacement. To maximize the search specificity and sensitivity, the search algorithm was generated by different combination of keywords including: fibrin sealant, fibrin tissue adhesive, fibrin glue, total knee replacement, total knee arthroplasty, TKR, TKA and their corresponding medical subject heading $(\mathrm{MeSH})$ terms. There is no language restriction on the language of the publication. All articles were imported into Endnote and reviewed to identify any omitted studies. The result of search strategy was presented in Figure 1.

\section{Inclusion and exclusion criteria}

Studies met the following inclusion criteria were included. (1) randomized controlled trials. (2) the only intervention considered was the use of fibrin sealant versus no fibrin sealant or placebo or standard care. Other interventions including drugs and functional recovery training, were permitted only when comparable of the interested intervention. (3) the main outcomes including: knee range of motion, total blood loss, blood transfusion rate. The secondary outcomes including hemoglobulin reduction, hospital stay, and complications. All kinds of complications were included including fever, hematomas, thrombosis and arthropathy. Studies were excluded according to following criteria: (1) observational studies, retrospective studies, cohort studies, casecontrol studies, review, or case series or reports. (2) irrelevant studies. (3) the quality of studies was too low or outcome information was insufficient. Any disagreements were resolved by discussion or with a senior reviewer. 


\section{Data extraction and quality assessment}

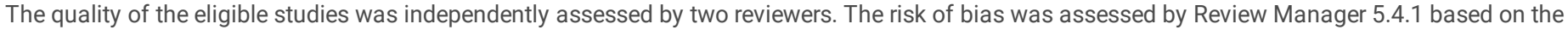

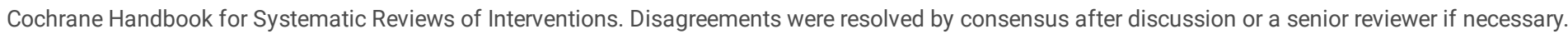

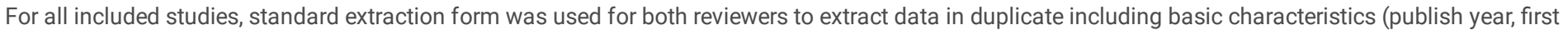

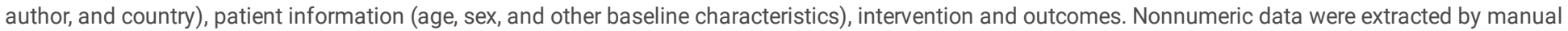
measurements of the published figures. The measurement data were converted to mean \pm SD according to the Cochrane Handbook.

\section{Statistical analysis}

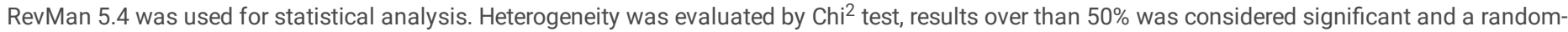

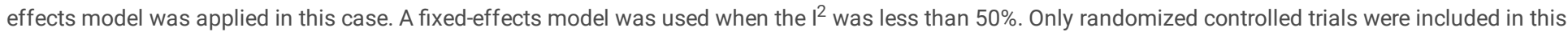

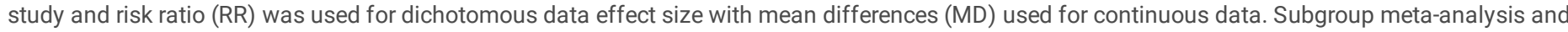
sensitivity analysis were performed accordingly.

\section{Results}

\section{Flow diagram of trial selection}

Figure 1 presented the detailed steps of our literature search. At first, a total of 675 of records were identified through database searching and 21 of additional records were identified through other sources. After duplicates removed, there are totally 599 of records screened and 563 of records were excluded after reading the titles and abstracts. 36 of records left were assessed for eligibility by full-text. Any researches other than RCT were excluded. Researches lack intact data were also excluded. Finally, 23 RCT studies fully met the inclusion criteria were included enrolling a total of 2267 participants. Of these, eight studies reported knee range of motion data with different time points, each time points were deemed as independent trails. Notarnicola's study reported two different doses of fibrin sealant and each dose was considered as an independent trail. In general, there were 1136 patients in the fibrin sealant group and 1131 patients in the control group. The characteristics of studies included were summarized in Table 1. The risk of bias summary was presented by Figure 2 and Figure 3. 
Table 1

Characteristics of the included studies

\begin{tabular}{|c|c|c|c|c|c|c|c|c|c|c|}
\hline $\begin{array}{l}\text { Study } \\
\text { (Year) }\end{array}$ & Country & $\begin{array}{l}\text { Cases } \\
\text { (FS/Co) }\end{array}$ & $\begin{array}{l}\text { Mean Age } \\
\text { (FS/Co) }\end{array}$ & $\begin{array}{l}\text { Male/Female } \\
\text { (Fs) }\end{array}$ & $\begin{array}{l}\text { Male/Female } \\
\text { (Co) }\end{array}$ & $\begin{array}{l}\text { BMI } \\
\text { (FS/Co) }\end{array}$ & Doses & $\begin{array}{l}\text { Origin of } \\
\text { FS }\end{array}$ & $\begin{array}{l}\text { Operation } \\
\text { methods }\end{array}$ & Drainage \\
\hline $\begin{array}{l}\text { Aguilera } \\
2013\end{array}$ & Spain & $43 / 43$ & 72.6/74.9 & $7 / 36$ & $7 / 36$ & $30.1 / 29.8$ & $4-8 \mathrm{ml}$ & $\begin{array}{l}\text { Product } \\
\text { fibrin }\end{array}$ & $\begin{array}{l}\text { Primary } \\
\text { TKR }\end{array}$ & Yes \\
\hline & & & & & & & & glue & & \\
\hline Bae 2014 & Korea & $50 / 50$ & $68.8 / 69$ & $4 / 46$ & $8 / 42$ & $26.41 / 24.81$ & $5 \mathrm{ml}$ & Floseal & $\begin{array}{l}\text { Unilateral } \\
\text { TKR }\end{array}$ & Yes \\
\hline $\begin{array}{l}\text { Bloomfield } \\
2012\end{array}$ & America & $50 / 50$ & $66.3 / 62.4$ & $22 / 28$ & $21 / 29$ & 33.9/33.4 & $10 \mathrm{ml}$ & $\begin{array}{l}\text { Autologous } \\
\text { PRP with } \\
\text { thrombin }\end{array}$ & $\begin{array}{l}\text { Primary } \\
\text { unilateral } \\
\text { TKR }\end{array}$ & No \\
\hline $\begin{array}{l}\text { Di } \\
\text { Francesco } \\
2013\end{array}$ & Italy & $51 / 42$ & $67.9 / 70.2$ & $24 / 27$ & $17 / 24$ & $26.5 / 26.2$ & $10 \mathrm{ml}$ & Floseal & $\begin{array}{l}\text { Unilateral } \\
\text { TKR }\end{array}$ & Yes \\
\hline Hesse 2014 & USA & $100 / 100$ & $66.33 / 67.85$ & NS & NS & $31.91 / 30.82$ & $10 \mathrm{ml}$ & Evicel & $\begin{array}{l}\text { Unilateral } \\
\text { TKR }\end{array}$ & Yes \\
\hline $\begin{array}{l}\text { Horstmann } \\
2011\end{array}$ & Netherland & $20 / 20$ & $67 / 66$ & $14 / 6$ & $13 / 7$ & NS & $11 \mathrm{ml}$ & $\begin{array}{l}\text { Autologous } \\
\text { PRP }\end{array}$ & TKR & Yes \\
\hline Kim 2012 & America & $97 / 99$ & NS & NS & NS & NS & $10 \mathrm{ml}$ & Floseal & $\begin{array}{l}\text { Primary } \\
\text { TKR }\end{array}$ & Yes \\
\hline Kluba 2012 & Germany & $12 / 12$ & $70.8 / 71$ & $6 / 6$ & $4 / 8$ & NS & $2 \mathrm{ml}$ & Quixil & $\begin{array}{l}\text { Bilateral } \\
\text { TKR }\end{array}$ & Yes \\
\hline Levy 1999 & Isreal & $29 / 29$ & $68.9 / 70.2$ & $23 / 6$ & $23 / 6$ & $29.8 / 29.1$ & $\begin{array}{l}10- \\
20 \mathrm{ml}\end{array}$ & Quixil & $\begin{array}{l}\text { Unilateral } \\
\text { TKR }\end{array}$ & Yes \\
\hline $\begin{array}{l}\text { McConnell } \\
2012\end{array}$ & UK & $21 / 22$ & NS & NS & NS & $31.5 / 30$ & $10 \mathrm{ml}$ & NS & TKR & Yes \\
\hline $\begin{array}{l}\text { Molloy } \\
2007\end{array}$ & England & $50 / 50$ & NS & NS & NS & $29.31 / 28.03$ & $10 \mathrm{ml}$ & Product & $\begin{array}{l}\text { Primary } \\
\text { TKR }\end{array}$ & NS \\
\hline $\begin{array}{l}\text { Morishita } \\
2014\end{array}$ & Japan & $20 / 20$ & 72/74.7 & $2 / 18$ & $0 / 20$ & $26.5 / 25.4$ & $10 \mathrm{ml}$ & $\begin{array}{l}\text { Autologous } \\
\text { PRP }\end{array}$ & $\begin{array}{l}\text { Unilateral } \\
\text { TKR }\end{array}$ & No \\
\hline $\begin{array}{l}\text { Pavao } \\
2019\end{array}$ & Spain & $32 / 31$ & $69.19 / 69.48$ & $4 / 28$ & $5 / 26$ & $31.81 / 31.23$ & $6 \mathrm{ml}$ & Evicel & $\begin{array}{l}\text { Primary } \\
\text { TKR }\end{array}$ & NS \\
\hline $\begin{array}{l}\text { Randelli } \\
2014\end{array}$ & Italy & $31 / 31$ & $69 / 71$ & $26 / 31$ & $22 / 31$ & $28 / 29$ & $5 \mathrm{ml}$ & Evicel & $\begin{array}{l}\text { Primary } \\
\text { TKR }\end{array}$ & Yes \\
\hline $\begin{array}{l}\text { Romanò } \\
2015\end{array}$ & Italy & $24 / 24$ & 71.7/71.2 & $7 / 17$ & $8 / 16$ & NS & $12 \mathrm{ml}$ & Floseal & $\begin{array}{l}\text { Primary } \\
\text { TKR }\end{array}$ & No \\
\hline $\begin{array}{l}\text { Sabatini } \\
2012\end{array}$ & Italy & $35 / 35$ & 70.7/70.4 & $10 / 25$ & $6 / 29$ & NS & $10 \mathrm{ml}$ & Quixil & TKR & Yes \\
\hline $\begin{array}{l}\text { Skovgaard } \\
2013\end{array}$ & Denmark & $24 / 24$ & $65 / 65$ & $11 / 13$ & $11 / 13$ & $28 / 28$ & $10 \mathrm{ml}$ & Evicel & $\begin{array}{l}\text { Bilateral } \\
\text { TKR }\end{array}$ & Yes \\
\hline $\begin{array}{l}\text { Suarez } \\
2014\end{array}$ & America & $54 / 54$ & $65.9 / 65.1$ & $20 / 36$ & $21 / 31$ & 29.8/33.7 & $10 \mathrm{ml}$ & Product & $\begin{array}{l}\text { Primary } \\
\text { TKR }\end{array}$ & Yes \\
\hline $\begin{array}{l}\text { Tandogan } \\
2021\end{array}$ & Turkey & $40 / 40$ & $68 / 70$ & $5 / 35$ & $4 / 36$ & $30.77 / 31.39$ & $5 \mathrm{ml}$ & $\begin{array}{l}\text { Autologous } \\
\text { PRP }\end{array}$ & $\begin{array}{l}\text { Primary } \\
\text { TKR }\end{array}$ & Yes \\
\hline Vera 2018 & Netherland & $234 / 232$ & $68 / 68$ & $82 / 152$ & $86 / 148$ & $29 / 29$ & $10 \mathrm{ml}$ & Cryoseal & $\begin{array}{l}\text { Primary } \\
\text { TKR }\end{array}$ & No \\
\hline Wang 2001 & America & $25 / 28$ & NS & NS & NS & NS & $10 \mathrm{ml}$ & Quixil & $\begin{array}{l}\text { Unilateral } \\
\text { TKR }\end{array}$ & Yes \\
\hline Yan 2021 & China & $34 / 35$ & $69.71 / 6.79$ & $6 / 28$ & $3 / 32$ & $29.38 / 28.59$ & $10 \mathrm{ml}$ & Floseal & TKR & Yes \\
\hline $\begin{array}{l}\text { Notarnicola } \\
2012(5 \mathrm{ml})\end{array}$ & Italy & $30 / 30$ & NS & $19 / 41$ & $19 / 41$ & NS & $5 \mathrm{ml}$ & Quixil & TKR & Yes \\
\hline $\begin{array}{l}\text { Notarnicola } \\
2012(10 \mathrm{ml})\end{array}$ & Italy & $30 / 30$ & NS & $21 / 39$ & $21 / 39$ & NS & $10 \mathrm{ml}$ & Quixil & TKR & Yes \\
\hline
\end{tabular}

Abbreviation: BMI, Body mass index; Fs, Fibrin sealant; Co, Control; NS, not stated. 


\section{Quality assessment}

The Cochrane Handbook for Systematic Reviews of Interventions was used to evaluated the risk of bias for all eligible studies by two independent reviewers. The results presented in Figure 2 and Figure 3. For all studies, one study was high risk on blinding of participants and personnel (performance bias). And there were two studies with high risk on blinding of outcome assessment (detection bias). Totally, the results of quality assessment indicated a small overall bias and relatively high quality.

\section{Effects on knee range of motion}

A total of eight studies reported data on knee range of motion using different time points[13-20], lacking consistency and comparability. Thus, a subgroup analysis was performed with four time intervals: 0 days - 3 days, 3 days - 1 week, 1 week - 1 months, 1 months - 3 months, each time points of articles were deemed as independent trails. Notarnicola's study reported two doses of fibrin sealant and each dose was considered as an independent trail. Random-effects model was used for large heterogeneity $\left(\mathrm{I}^{2}=93 \%\right)$. The results showed significant difference between fibrin sealant group and control group during at 3 days to 1 month $[95 \% \mathrm{Cl}(2.50,22.42) ; \mathrm{p}=0.01]$. No statistical difference was found at the other time intervals as well as in total $[95 \% \mathrm{Cl}(-1.17,9.29), \mathrm{P}=0.13](\mathrm{Figure} 4)$.

\section{Effects on total blood loss}

A total of 21 studies reported intact data related to blood loss[15-36]. Among these studies, 6 studies solely reported intact data on drain-out blood loss[16, 17, $19,21,25,37]$ and 11 studies solely reported intact data on total blood loss[18, 20, 23, 26-36, 38], while 4 studies reported intact data on both drain-out blood loss and total blood loss $[23,26,33,35]$. Thus, we performed a subgroup analysis for drain-out blood loss and total blood loss. Random-effects model was used in both subgroup analysis due to significant heterogenicity. Results showed that fibrin sealant significantly reduced drain-out blood loss compared to control group [95\% Cl $(-2383.37,-376.45), P=0.007$ ] while failed to reach statistical significance in total blood loss reduction [95\% Cl $(-249.53,37.28), \mathrm{P}=0.15]$ (Figure 5). Totally, the usage of fibrin sealant reduced total blood loss [95\% (-935.81, -351.70), P<0.0001].

\section{Effects on blood transfusion rate}

Totally 16 studies provided data on blood transfusion rate and the results indicated significant heterogeneity $\left(I^{2}=56 \%, P=0.003\right)[15,17-20,23,25,26,28,30$, $32,34-36,38,39]$. Radom-effects model was applied and results showed that fibrin sealant administration reduced the blood transfusion rate compared with the control group $[95 \% \mathrm{Cl}(0.47,0.90), \mathrm{P}=0.01]$ (Figure 6). Fibrin sealant might reduce the transfusion rate of total knee replacement.

\section{Effects on hemoglobulin reduction}

Based on the inclusion criteria, a total of 9 studies providing data of hemoglobulin reduction were included in this study (Figure 7$)[15,17,23,25,26,30,34$, $35,39]$. Significant difference between fibrin sealant group and control group was observed [95\% $\mathrm{Cl}(-2.94,-0.74), \mathrm{P}=0.001]$.

\section{Effects on hospital stay}

Eight eligible studies reported the time of hospital stay [17-19, 21, 23, 26, 33, 35]. Analysis of these studies revealed statistically significant difference between the fibrin sealant group and control group indicating using fibrin sealant may reduce the time of hospital stay $[95 \% \mathrm{Cl}(-1.76,-0.42), \mathrm{P}=0.001](\mathrm{Figure} 8)$.

\section{Effects on complication}

Seventeen studies reported intact data of complication including fever, hematoma, thrombosis, and arthropathy [12, 15, 17-21, 25-27, 29, 30, 32, 34, 36, 38, 39]. The analysis of these studies exhibited no significant difference between the fibrin sealant group and the control group, demonstrating using fibrin sealant may not interfere the rate of complication $[95 \% \mathrm{Cl}(-0.04,0.02), \mathrm{P}=0.42]$.

\section{Sensitivity Analysis}

To enhance the credibility and determine the origin of heterogenicity, we conducted sensitivity analysis by removing each study at a time and recalculating the meta-analysis for the remaining studies, results showed a similar trend which confirmed stability of our analysis of range of motion, total blood loss, hemoglobulin reduction, transfusion rate, hospital stay, and complication.

\section{Discussion}

The present meta-analysis indicated that the usage of fibrin sealant in total knee replacement may reduce the total blood loss, transfusion rate, hemoglobulin reduction and hospital stay, but the effect of knee range of motion and complication was not significant. In this study, only randomized controlled trials were included, resulting in 23 studies for the meta-analysis. 
Most studies used $10 \mathrm{ml}$ as the dosage of fibrin sealant and both unilateral and bilateral total knee replacement were included. Although fibrin sealant has been used in surgical procedures for decades, the effects of fibrin sealant on total knee replacement still lack consensus. Previous studies mostly focused on hemostasis effect of fibrin sealant and topics related to blood loss, including total blood loss, hemoglobulin reduction and blood transfusion[10, 40]. However, as the requirement of rapid recovery increased, reducing hospital stay and promoting functional restoration become much more urgent. Knee range of motion, the key indicator of discharge and knee functional recovery, is very important but usually forgotten or underestimated in the precious studies [3, 10, 40]. We aimed to evaluate the effect of fibrin sealant on enhanced recovery after surgery (ERAS) of total knee replacement and focused on the knee range of motion and hemostasis as well.

The group treated with fibrin sealant had a lower total blood loss, transfusion rate, and hemoglobin reduction indicating the usage of fibrin sealant is helpful in blood loss control. Although recently published RCTs reported no effect of fibrin sealant on blood loss after total knee replacement. Our research still supported the usage of fibrin sealant on total knee replacement for hemostasis. We assume the reasons may be the different types of fibrin sealant used. As presented in Table 1, folseal, Evicel and Quixil were three most common fibrin sealant used which contains tranexamic acid. However, as Randelli et al. reported, some fibrin sealants were derived from human plasma and contains only human components without tranexamic acid which is an effective hemostasis agent for fibrinolysis inhibition.

There are 8 studied provided intact data of knee range of motion [13-20], but each study used different time points set by author. For consistency, we concluded these time points into four time intervals and performed subgroup meta-analysis, each time points were referred as an independent trail. For intervals of 3 days to 1 week, results demonstrated that the usage of fibrin sealant might help the improvement of knee range of motion. However, analysis of the rest time intervals failed to reveal significant difference as well as in total. We have noticed a significant heterogenicity of $3 \mathrm{~d}-1 \mathrm{w}$ interval and the heterogenicity of total analysis was mostly from this time interval. Thus, we performed a sensitivity analysis, results displayed a similar trend which indicated that our analysis was stable. Studies reporting intact date of range of motion always reported it with different time points which varied a lot between different trials. However, previous analysis of fibrin sealant focused mostly on hemostasis effect but paid insufficient attention to knee function restoration and were outdated $[3,10,40]$. Knee range of motion was frequently regarded as a secondary outcome and analyzed in one piece with large heterogenicity. Different from previous studies [7], we divided it into four time intervals and found a opposite result. Only in 3 days to 1 week, using fibrin sealant may help the improvement of knee range of motion. But in the other time intervals and in total, using fibrin sealant was not helpful for knee range of motion recovery. On the other hand, using fibrin sealant during total knee replacement may not hinder the knee range of motion recovery. As a derivative of fibrin, the main component of scars, fibrin sealant may exacerbate the scarring and adhesions after total knee replacement and further interfere the recovery of knee function. However, our research denied this hypothesis. What's more, our analysis also found using fibrin sealant may not increase the incidence of complications but decrease the time of hospital stay. In conclusion, using fibrin sealant was considered safe for knee function restoration.

Although standard procedures and careful assessment were performed in this meta-analysis, some potential limitations still exist: (1) differences of dose and compound of fibrin sealant may have an effect on the results. (2) clinical and statistical heterogeneity may reduce the credibility of final results.

In conclusion, patients undergoing total knee replacement would benefit from fibrin sealant with reduced total blood loss, transfusion rate, hemoglobulin reduction, and hospital stay but may benefit little from knee range of motion. Our study suggested that fibrin sealant use is effective and safe. While a large and well-designed randomized controlled trial is still needed to investigate the risks and benefits of the use of fibrin sealant.

\section{Abbreviations}

Total knee replacement (TKR)

Range of motion (ROM)

Fibrin sealant (FS)

Randomized controlled trials (RCTs)

Preferred Reporting Items for Systemic Reviews and Meta-Analysis (PRISMA)

Medical subject heading (MeSH)

Risk ratio (RR)

Mean differences (MD)

Enhanced recovery after surgery (ERAS)

Body mass index (BMI)

Control (Co)

Not stated (NS)

\section{Declarations}




\section{Ethics approval and consent to participate:}

not applicable.

\section{Consent for publication:}

All author had approved the version to be published.

\section{Availability of data and materials:}

This manuscript has no associated data or the data will not be deposited.

\section{Competing interests:}

The authors declare no conflict of interest. The funders had no role in the design of the study; in the collection, analyses, or interpretation of data; in the writing of the manuscript, or in the decision to publish the results.

\section{Funding:}

This research was funded by Yangzhou Municipal Meteorological Bureau, grant number: YZ2020116.

\section{Authors' contributions:}

All author had made substantial contributions to the conception or design of the work; or the acquisition, analysis, or interpretation of data; or the creation of new software used in the work. All author agreed to be accountable for all aspects of the work in ensuring that questions related to the accuracy or integrity of any part of the work are appropriately investigated and resolved.

\section{Acknowledgements:}

not applicable.

\section{References}

1. Kurtz S, Ong K, Lau E, Mowat F, Halpern M (2007) Projections of primary and revision hip and knee arthroplasty in the United States from 2005 to 2030. J Bone Joint Surg Am 89:780-785. DOI 10.2106/JBJS.F.00222

2. Verra WC, van Hilten JA, Honohan A, van Zwet EW, van der Bom JG, Nelissen R, group FI-r (2018) The effect of a fibrin sealant on knee function after total knee replacement surgery. Results from the FIRST trial. A multicenter randomized controlled trial. PLoS One 13:e0200804. DOI 10.1371/journal.pone.0200804

3. Yang TQ, Geng XL, Ding MC, Yang MX, Zhang Q (2015) The efficacy of fibrin sealant in knee surgery: A meta-analysis. Orthop Traumatol Surg Res 101:331-339. DOI 10.1016/j.otsr.2014.07.035

4. Xie J, Yu H, Wang F, Jing J, Li J (2021) A comparison of thrombosis in total knee arthroplasty with and without a tourniquet: a meta-analysis of randomized controlled trials. J Orthop Surg Res 16:408. DOI 10.1186/s13018-021-02366-w

5. Tai TW, Lin CJ, Jou IM, Chang CW, Lai KA, Yang CY (2011) Tourniquet use in total knee arthroplasty: a meta-analysis. Knee Surg Sports Traumatol Arthrosc 19:1121-1130. DOI 10.1007/s00167-010-1342-7

6. Radosevich M, Goubran HI, Burnouf T (1997) Fibrin sealant: scientific rationale, production methods, properties, and current clinical use. Vox Sang 72:133-143. DOI 10.1046/j.1423-0410.1997.7230133.x

7. Wang H, Shan L, Zeng H, Sun M, Hua Y, Cai Z (2014) Is fibrin sealant effective and safe in total knee arthroplasty? A meta-analysis of randomized trials. J Orthop Surg Res 9:36. DOI 10.1186/1749-799X-9-36

8. Liu J, Cao JG, Wang L, Ma XL (2014) Effect of fibrin sealant on blood loss following total knee arthroplasty: a systematic review and meta-analysis. Int J Surg 12:95-102. DOI 10.1016/j.jjsu.2013.11.011

9. Li ZJ, Fu X, Tian P, Liu WX, Li YM, Zheng YF, Ma XL, Deng WM (2015) Fibrin sealant before wound closure in total knee arthroplasty reduced blood loss: a meta-analysis. Knee Surg Sports Traumatol Arthrosc 23:2019-2025. DOI 10.1007/s00167-014-2898-4

10. Li J, Li HB, Zhai XC, Qin L, Jiang XQ, Zhang ZH (2016) Topical use of topical fibrin sealant can reduce the need for transfusion, total blood loss and the volume of drainage in total knee and hip arthroplasty: A systematic review and meta-analysis of 1489 patients. Int J Surg 36:127-137. DOI 10.1016/j.ijsu.2016.10.022

11. Chen X, Yang W, Wang X (2019) Is bipolar sealer superior than standard electrocautery for blood loss control after primary total knee arthroplasty: A metaanalysis. Medicine (Baltimore) 98:e17762. DOI 10.1097/MD.0000000000017762 
12. Verra WC, van Hilten JA, Honohan Á, van Zwet EW, van der Bom JG, Nelissen R (2018) The effect of a fibrin sealant on knee function after total knee replacement surgery. Results from the FIRST trial. A multicenter randomized controlled trial. PLoS One 13:e0200804. DOI 10.1371/journal.pone.0200804

13. Heyse TJ, Haas SB, Drinkwater D, Lyman S, Kim HJ, Kahn BA, Figgie MP (2014) Intraarticular fibrinogen does not reduce blood loss in TKA: A randomized clinical trial knee. Clinical Orthopaedics and Related Research 472:272-276. DOI 10.1007/s11999-013-3036-1

14. Horstmann WG, Ettema HB, Verheyen CCPM (2010) Dutch orthopedic blood management surveys 2002 and 2007: an increasing use of blood-saving measures. Archives of Orthopaedic and Trauma Surgery 130:55-59. DOI 10.1007/s00402-009-0910-0

15. Kim HJ, Fraser MR, Kahn B, Lyman S, Figgie MP (2012) The efficacy of a thrombin-based hemostatic agent in unilateral total knee arthroplasty: a randomized controlled trial. J Bone Joint Surg Am 94:1160-1165. DOI 10.2106/jbjs.K.00531

16. Skovgaard C, Holm B, Troelsen A, Lunn TH, Gaarn-Larsen L, Kehlet H, Husted H (2013) No effect of fibrin sealant on drain output or functional recovery following simultaneous bilateral total knee arthroplasty: A randomized, double-blind, placebo-controlled study. Acta Orthopaedica 84:153-158. DOI $10.3109 / 17453674.2013 .769082$

17. Notarnicola A, Moretti L, Martucci A, Spinarelli A, Tafuri S, Pesce V, Moretti B (2012) Comparative efficacy of different doses of fibrin sealant to reduce bleeding after total knee arthroplasty. Blood Coagulation and Fibrinolysis 23:278-284. DOI 10.1097/MBC.0b013e3283518846

18. Bloomfield MR, Klika AK, Molloy RM, Froimson MI, Krebs VE, Barsoum WK (2012) Prospective randomized evaluation of a collagen/thrombin and autologous platelet hemostatic agent during total knee arthroplasty. J Arthroplasty 27:695-702. DOI 10.1016/j.arth.2011.09.014

19. Kluba T, Fiedler K, Kunze B, Ipach I, Suckel A (2012) Fibrin sealants in orthopaedic surgery: practical experiences derived from use of QUIXIL (R) in total knee arthroplasty. Archives of Orthopaedic and Trauma Surgery 132:1147-1152. DOI 10.1007/s00402-012-1519-2

20. Morishita M, Ishida K, Matsumoto T, Kuroda R, Kurosaka M, Tsumura N (2014) Intraoperative Platelet-Rich Plasma Does Not Improve Outcomes of Total Knee Arthroplasty. Journal of Arthroplasty 29:2337-2341. DOI 10.1016/j.arth.2014.04.007

21. Horstmann WG, Slappendel R, van Hellemondt GG, Wymenga AW, Jack N, Everts PAM (2011) Autologous platelet gel in total knee arthroplasty: a prospective randomized study. Knee Surgery Sports Traumatology Arthroscopy 19:115-121. DOI 10.1007/s00167-010-1207-0

22. Pavao DM, Palhares GM, Albuquerque RSPE, de Sousa EB, Barretto JM (2019) Prospective Study on the Impact of the Use of Human Fibrin Sealant free of Clot-Stabilizing Agents in Total Knee Arthroplasty. Revista brasileira de ortopedia 54:322-328. DOI 10.1055/s-0039-1692447

23. Randelli F, D'Anchise R, Ragone V, Serrao L, Cabitza P, Randelli P (2014) Is the newest fibrin sealant an effective strategy to reduce blood loss after total knee arthroplasty? A randomized controlled study. Journal of Arthroplasty 29:1516-1520. DOI 10.1016/j.arth.2014.02.024

24. Saleh A, Hebeish M, Farias-Kovac M, Klika AK, Patel P, Suarez J, Barsoum WK (2014) Use of Hemostatic Agents in Hip and Knee Arthroplasty: A Critical Analysis Review. JBJS reviews 2. DOI 10.2106/jbjs.Rvw.M.00061

25. Wang GJ, Hungerford DS, Savory CG, Rosenberg AG, Mont MA, Burks SG, Mayers SL, Spotnitz WD (2001) Use of fibrin sealant to reduce bloody drainage and hemoglobin loss after total knee arthroplasty: A brief note on a randomized prospective trial. Journal of Bone and Joint Surgery - Series A 83:15031505. DOI 10.2106/00004623-200110000-00007

26. Yen SH, Lin PC, Wu CT, Wang JW (2021) Comparison of Effects of a Thrombin-Based Hemostatic Agent and Topical Tranexamic Acid on Blood Loss in Patients with Preexisting Thromboembolic Risk Undergoing a Minimally Invasive Total Knee Arthroplasty. A Prospective Randomized Controlled Trial. Biomed Res Int 2021:2549521. DOI 10.1155/2021/2549521

27. Bae KC, Cho CH, Lee KJ, Son ES, Lee SW, Lee SJ, Lim KH (2014) Efficacy of intra-articular injection of thrombin-based hemostatic agent in the control of bleeding after primary total knee arthroplasty. Knee Surg Relat Res 26:236-240. DOI 10.5792/ksrr.2014.26.4.236

28. Di Francesco A, Flamini S, Fiori F, Mastri F (2013) Hemostatic matrix effects on blood loss after total knee arthroplasty: A randomized controlled trial. Indian J Orthop 47:474-481. DOI 10.4103/0019-5413.118203

29. Heyse TJ, Haas SB, Drinkwater D, Lyman S, Kim HJ, Kahn BA, Figgie MP (2014) Intraarticular fibrinogen does not reduce blood loss in TKA: a randomized clinical trial. Clin Orthop Relat Res 472:272-276. DOI 10.1007/s11999-013-3036-1

30. Levy O, Martinowitz U, Oran A, Tauber C, Horoszowski H (1999) The use of fibrin tissue adhesive to reduce blood loss and the need for blood transfusion after total knee arthroplasty. A prospective, randomized, multicenter study. Journal of Bone and Joint Surgery - Series A 81:1580-1588. DOI 10.2106/00004623-199911000-00010

31. McConnell JS, Shewale S, Munro NA, Shah K, Deakin AH, Kinninmonth AW (2012) Reducing blood loss in primary knee arthroplasty: a prospective randomised controlled trial of tranexamic acid and fibrin spray. Knee 19:295-298. DOI 10.1016/j.knee.2011.06.004

32. Molloy DO, Archbold HAP, Ogonda L, McConway J, Wilson RK, Beverland DE (2007) Comparison of topical fibrin spray and tranexamic acid on blood loss after total knee replacement: A prospective, randomised controlled trial. Journal of Bone and Joint Surgery - Series B 89:306-309. DOI 10.1302/0301620X.89B3.17565

33. Pavão DM, Palhares GM, Albuquerque R, de Sousa EB, Barretto JM (2019) Prospective Study on the Impact of the Use of Human Fibrin Sealant free of Clot-Stabilizing Agents in Total Knee Arthroplasty. Rev Bras Ortop (Sao Paulo) 54:322-328. DOI 10.1055/s-0039-1692447

34. Sabatini L, Trecci A, Imarisio D, Uslenghi MD, Bianco G, Scagnelli R (2012) Fibrin tissue adhesive reduces postoperative blood loss in total knee arthroplasty. Journal of Orthopaedics and Traumatology 13:145-151. DOI 10.1007/s10195-012-0198-7

35. Suarez JC, Slotkin EM, Alvarez AM, Szubski CR, Barsoum WK, Patel PD (2014) Prospective, randomized trial to evaluate efficacy of a thrombin-based hemostatic agent in total knee arthroplasty. J Arthroplasty 29:1950-1955. DOI 10.1016/j.arth.2014.05.025

36. Tandogan RN, Polat M, Beyzadeoglu T, Karabulut E, Yildirim K, Kayaalp A (2021) Topical co-delivery of platelet rich fibrin and tranexamic acid does not decrease blood loss in primary total knee arthroplasty compared to the standard of care: a prospective, randomized, controlled trial. Knee surgery, sports traumatology, arthroscopy : official journal of the ESSKA 29:519-528. DOI 10.1007/s00167-020-05938-1

Page $8 / 14$ 
37. Kim HJ, Fraser R, Kahn B, Lyman S, Figgie MP (2012) The Efficacy of a Thrombin-Based Hemostatic Agent in Unilateral Total Knee Arthroplasty A Randomized Controlled Trial. Journal of Bone and Joint Surgery-American Volume 94A:1160-1165. DOI 10.2106/jbjs.K.00531

38. Aguilera X, Martinez-Zapata MJ, Bosch A, Uríutia G, Gonźalez JC, Jordan M, Gich I, Mayḿo RM, Martínez N, Monllau JC, Celaya F, Ferńandez JA (2013) Efficacy and safety of fibrin glue and tranexamic acid to prevent postoperative blood loss in total knee arthroplasty: A randomized controlled clinical trial. Journal of Bone and Joint Surgery - Series A 95:2001-2007. DOI 10.2106/JBJS.L.01182

39. Romanò CL, Monti L, Logoluso N, Romanò D, Drago L (2015) Does a thrombin-based topical haemostatic agent reduce blood loss and transfusion requirements after total knee revision surgery? A randomized, controlled trial. Knee Surg Sports Traumatol Arthrosc 23:3337-3342. D0I 10.1007/s00167014-3153-8

40. Xie J, Hu Q, Huang Q, Ma J, Lei Y, Pei F (2017) Comparison of intravenous versus topical tranexamic acid in primary total hip and knee arthroplasty: An updated meta-analysis. Thromb Res 153:28-36. DOI 10.1016/j.thromres.2017.03.009

\section{Figures}

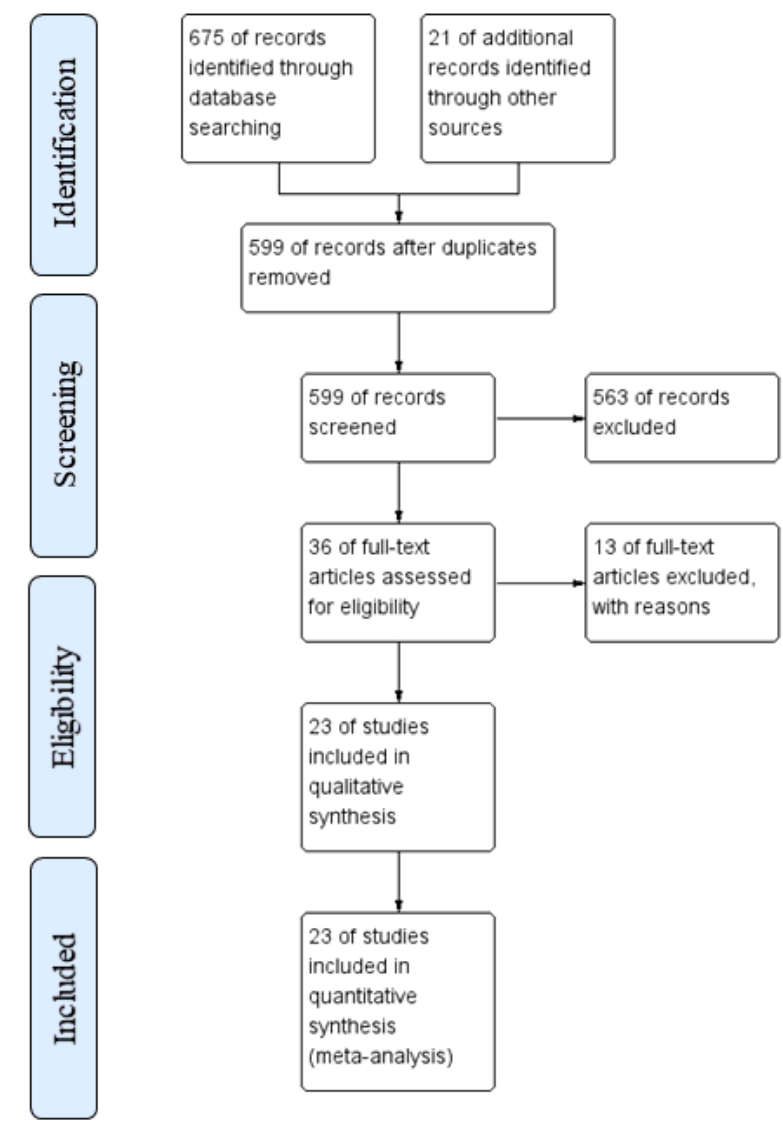

\section{Figure 1}

The flow diagram of the selection process 
Random sequence generation (selection bias)

Allocation concealment (selection bias)

Blinding of participants and personnel (performance bias)

Blinding of outcome assessment (detection bias)

Incomplete outcome data (attrition bias)

Selective reporting (reporting bias)

Other bias
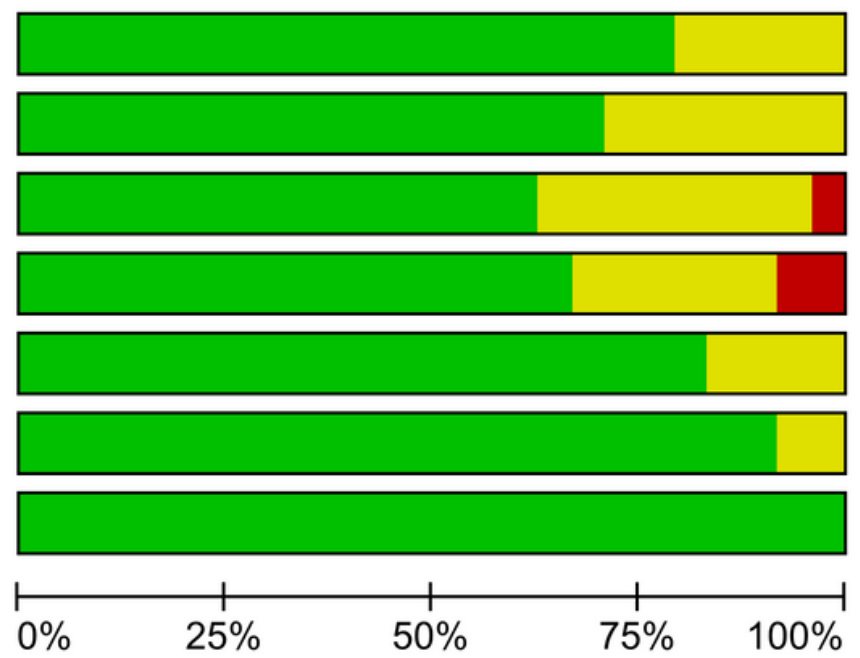

Low risk of bias

Unclear risk of bias

High risk of bias

Figure 2

The risk of bias summary

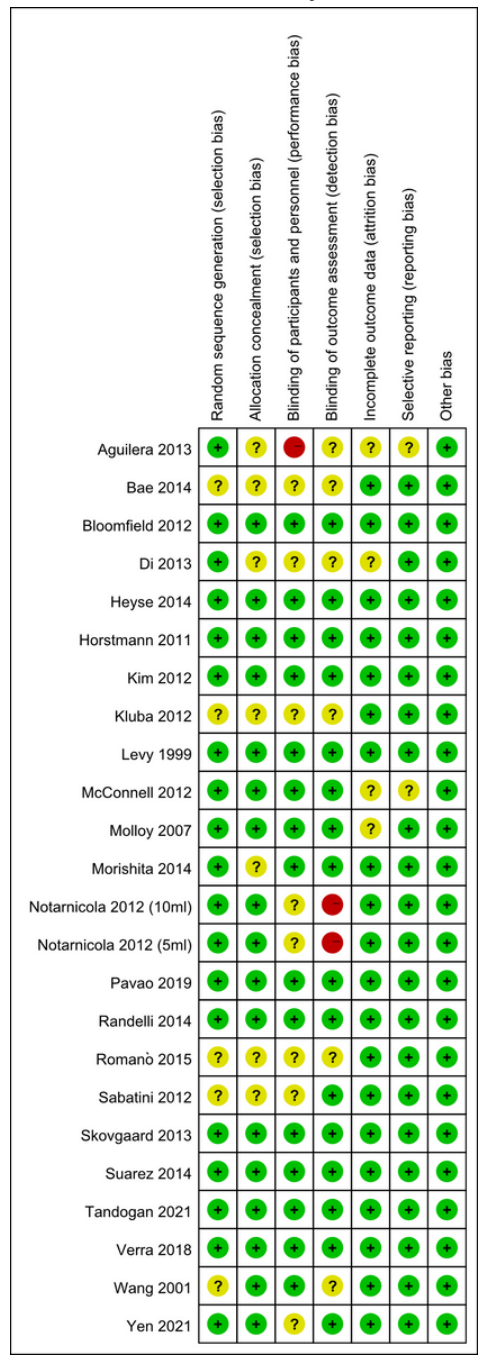

Figure 3

The risk of bias graph 


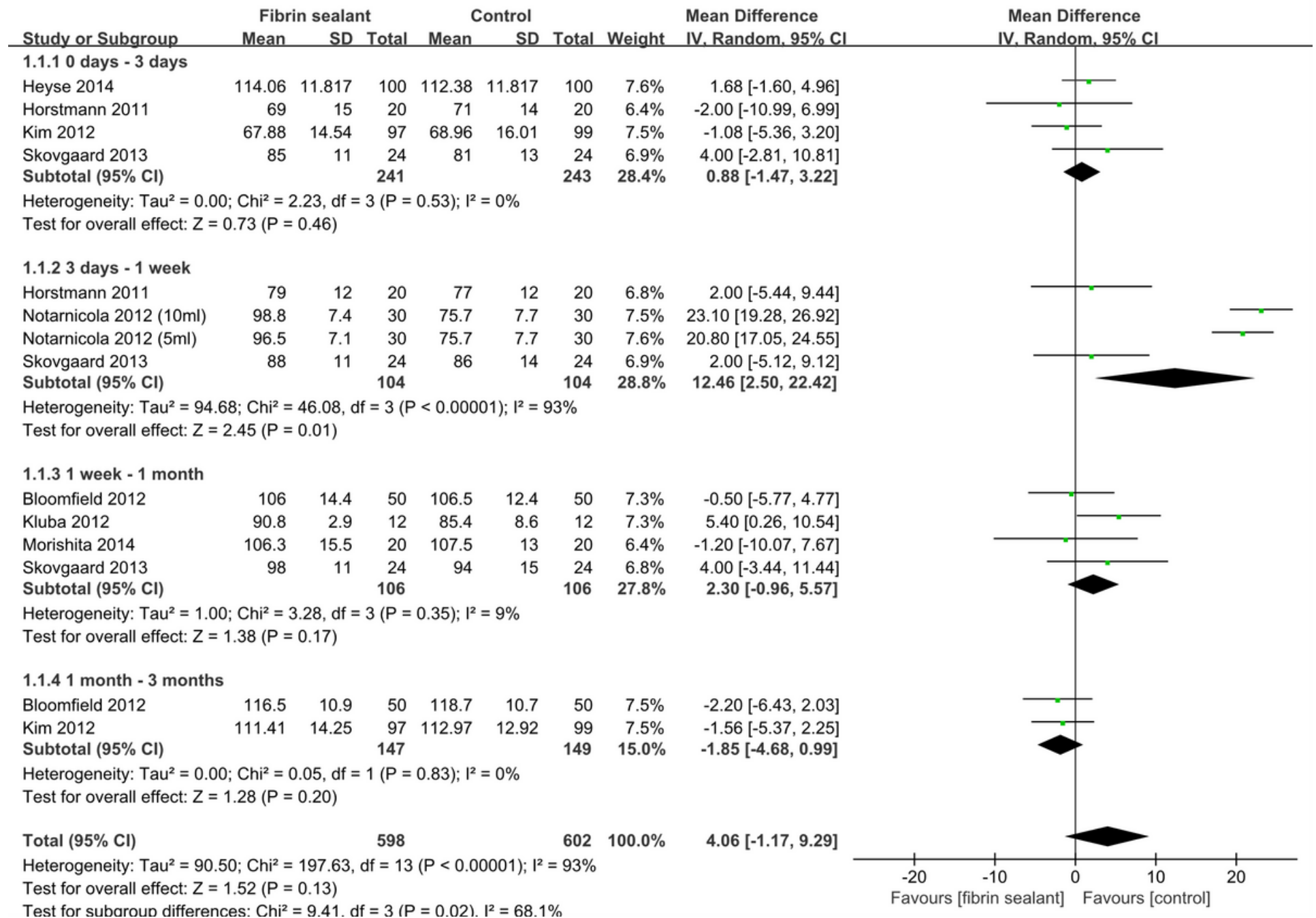

\section{Figure 4}

Subgroup meta-analysis of knee range of motion 


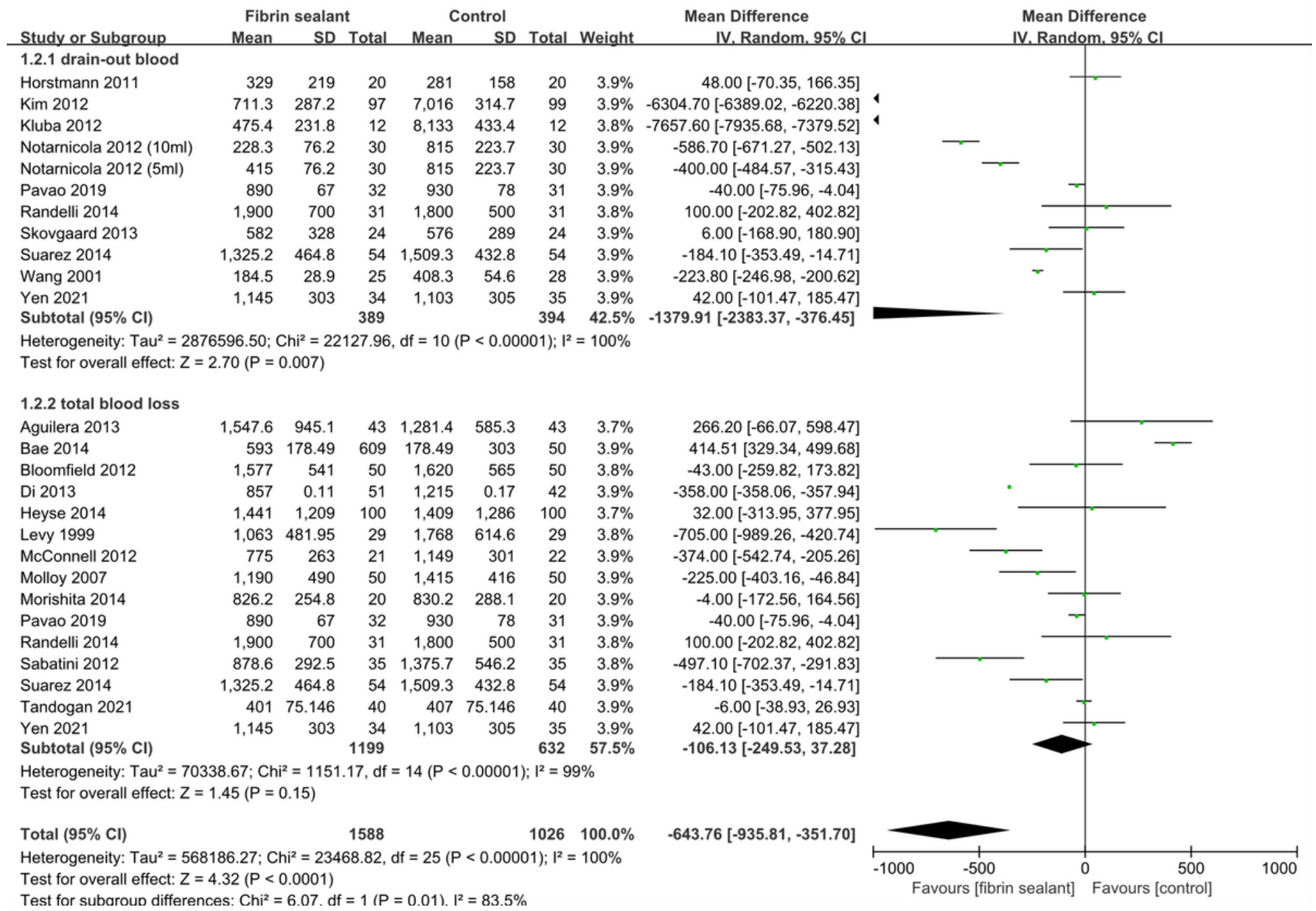

Figure 5

Subgroup meta-analysis of total blood loss

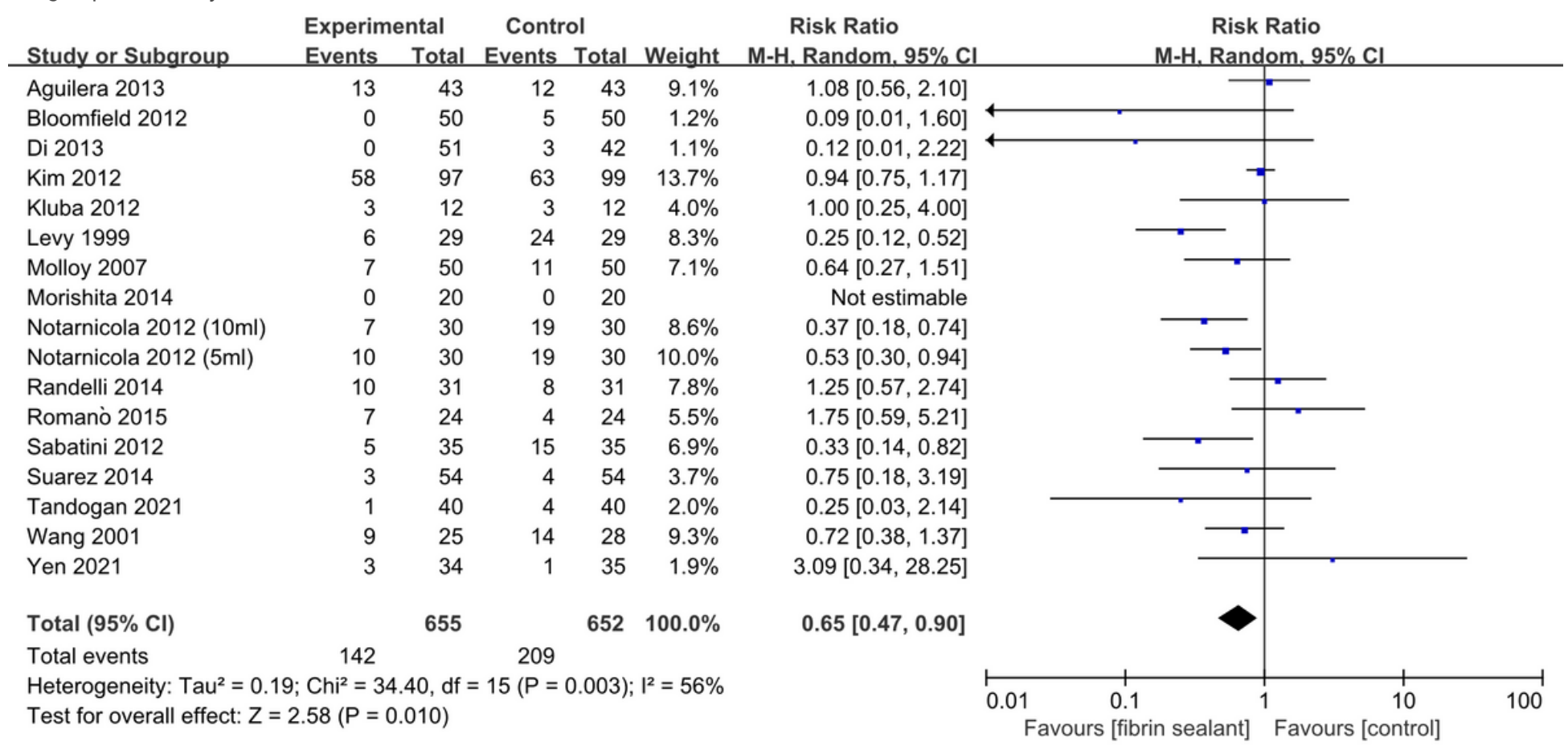


Meta-analysis of blood transfusion rate

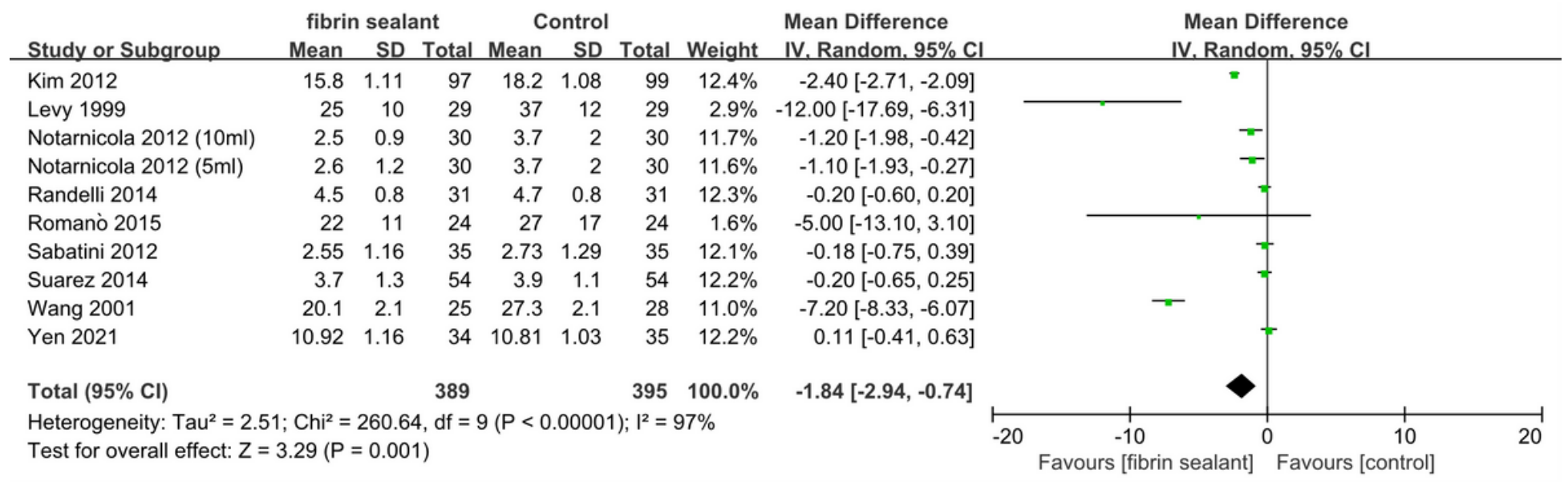

Figure 7

Effects on hemoglobulin reduction

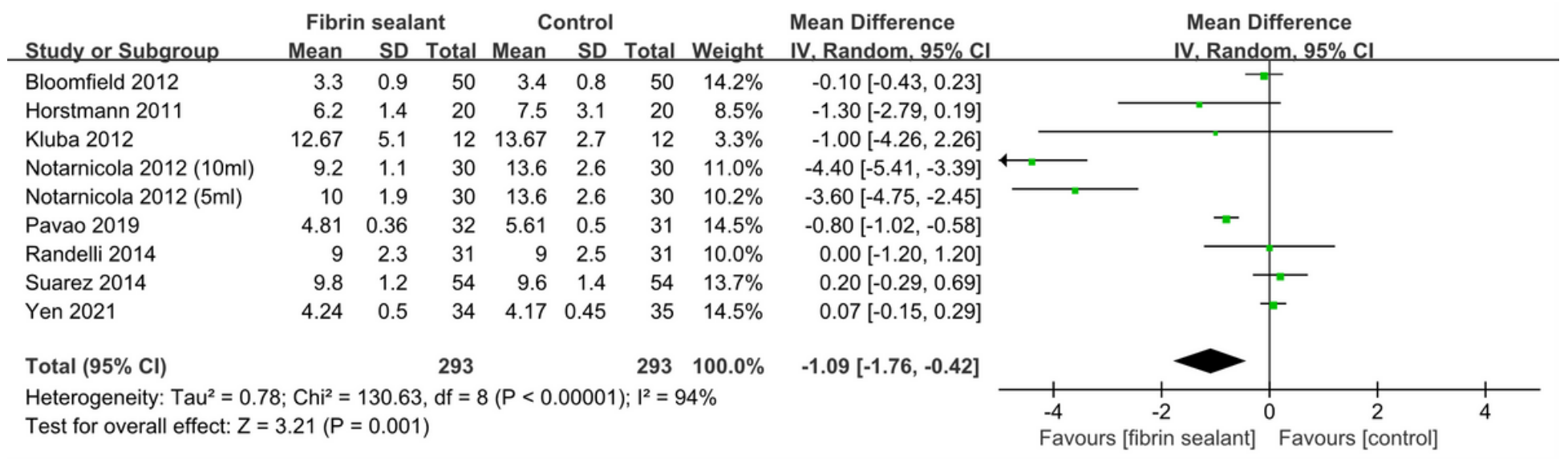

Figure 8

Effects on hospital stay 


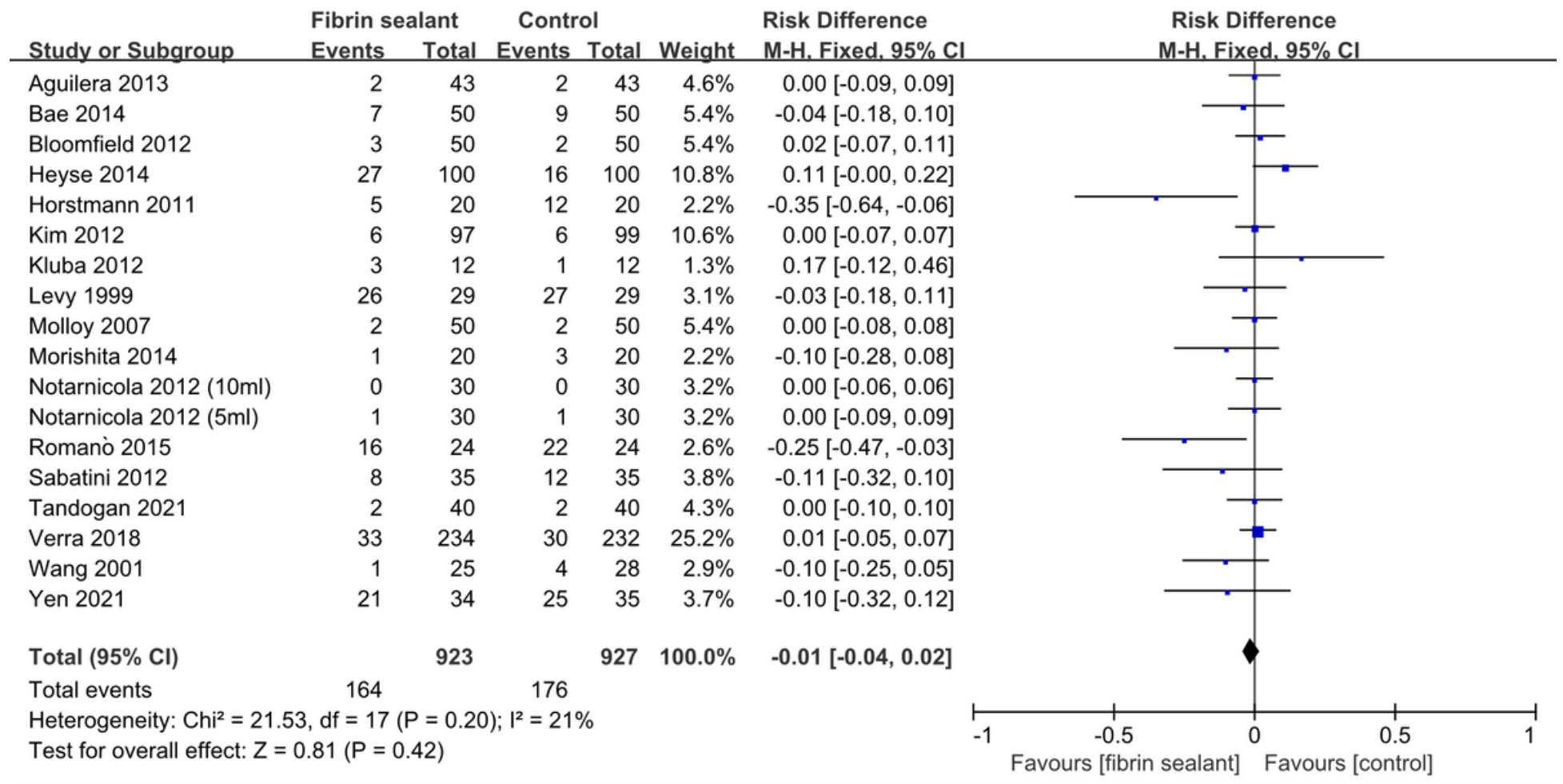

Figure 9

Effects on Complication 